\title{
Frost-Boil Ecosystems: Complex Interactions between Landforms, Soils, Vegetation and Climate
}

\author{
Donald A. Walker, ${ }^{*}$ Howard E. Epstein, ${ }^{2}$ William A. Gould, ${ }^{3}$ Alexia M. Kelley, ${ }^{2}$ Anja N. Kade, ${ }^{1}$ Julie A. Knudson, ${ }^{1}$ \\ William B. Krantz, ${ }^{4}$ Gary Michaelson, ${ }^{5}$ Rorik A. Peterson, ${ }^{6}$ Chien-Lu Ping, ${ }^{5}$ Martha K. Raynolds, ${ }^{1}$ \\ Vladimir E. Romanovsky ${ }^{6}$ and Yuri Shur ${ }^{7}$ \\ ${ }^{1}$ Institute of Arctic Biology and Department of Biology and Wildlife, University of Alaska Fairbanks, Fairbanks, \\ Alaska, USA \\ ${ }^{2}$ Department of Environmental Science, University of Virginia, Charlottesville, Virginia, USA \\ ${ }^{3}$ International Institute of Tropical Forestry, USDA Forest Service, San Juan, Puerto Rico \\ ${ }^{4}$ Department of Chemical Engineering, University of Cincinnati, Cincinnati, Ohio, USA \\ ${ }^{5}$ Palmer Research Center, University of Alaska Fairbanks, Palmer, Alaska, USA \\ ${ }^{6}$ Geophysical Institute and Department of Geology and Geophysics, University of Alaska Fairbanks, Alaska, USA \\ ${ }^{7}$ Civil and Environmental Engineering Department, University of Alaska Fairbanks, Alaska, USA
}

\begin{abstract}
Frost boils in northern Alaska vary from large, 2-3-m diameter, barren non-sorted circles to completely vegetated hummocks. Summer warmth increases southwards from the coast. Average thaw-layer thickness shows the opposite trend. Frost heave shows no trend along the climate gradient but is affected by soil texture. Heave is greatest on frost boils with fine-grained sediments. Biomass increases from $183 \mathrm{~g} \mathrm{~m}^{-2}$ at the coast to $813 \mathrm{~g} \mathrm{~m}^{-2}$ in the Arctic Foothills. An aggrading permafrost table is evident in most of the frost-boil soil profiles, indicating that, over time, accumulation of plant biomass leads to reduced thaw-layer thickness. A conceptual model suggests how vegetation affects the morphology of patterned ground forms. In the coldest parts of the High Arctic well-developed frost boils do not form and there is little vegetation on frost boils or the inter-boil areas. In the warmest parts of the Low Arctic, vegetation is usually sufficient to stabilize the frost boil soils. Frost boils play an important role in Arctic ecosystems functions, including the flux of trace gases to the atmosphere, flux of water and nutrients to streams, and the recycling of important nutrients to wildlife populations. Copyright (C) 2004 John Wiley \& Sons, Ltd.
\end{abstract}

\section{INTRODUCTION}

This paper presents observations of frost boils in northern Alaska. It presents a hypothesis of how vegetation affects small-scale patterned-ground features across the complete Arctic climate gradient. Although not directly part of the CircumpolarActive-Layer-Monitoring (CALM) project, frost boils influence the thaw layer and are relevant to CALM.

* Correspondence to: D. A. Walker, Institute of Arctic Biology and Wildlife, University of Alaska Fairbanks, Fairbanks, Alaska 99775, USA. E-mail: ffdaw@uaf.edu

Copyright (C) 2004 John Wiley \& Sons, Ltd.

\section{Frost Boil Terminology}

Frost boils are small, 0.5 to $3 \mathrm{~m}$ diameter, patches of barren or sparsely vegetated soil formed by frost action (Everdingen, 2002) (Figure 1). They are caused by differential frost heave in permafrost regions and occur in regular patterns over much of the Arctic. Although the term frost boil (=mud boil in the Canadian literature) has been widely used, the term is problematic for several reasons. First, evidence of active frost churning ('boiling') is often absent from the central portion of frost boils. Like many patterned Received 15 April 2003 Revised 28 February 2004 Accepted 10 March 2004 


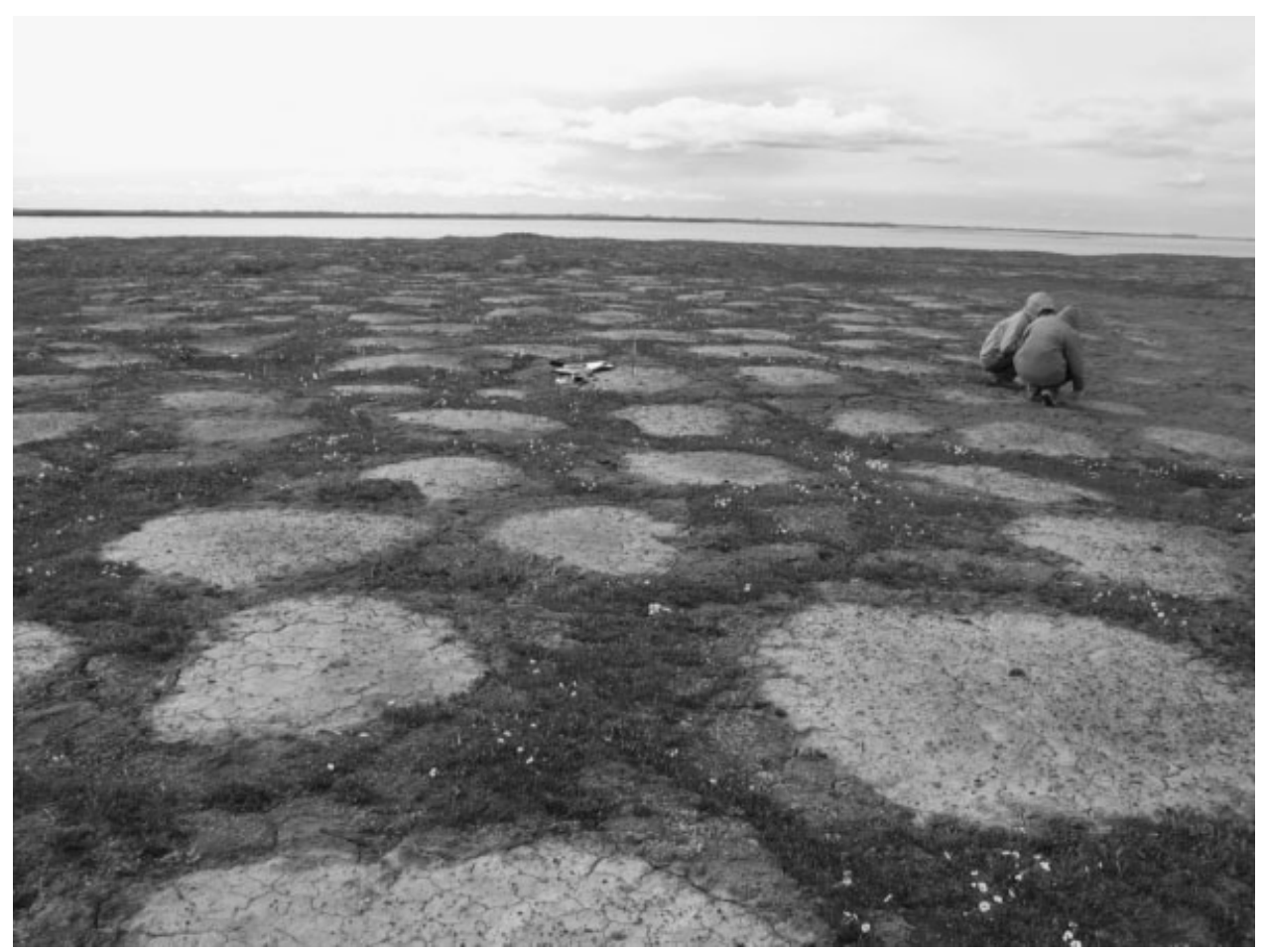

Figure 1 Frost boils on Howe Island, Sagavanirktok River delta, northern Alaska. The frost boils are 1-2 m in diameter.

ground forms, frost boils are formed by several interacting mechanisms including but not limited to differential frost heave, frost cracking, mass displacement, and sorting processes. Washburn (1980) used the term non-sorted circle to describe the form without reference to a specific genetic cause. Other terms, including frost medallion and frost scar, have also been proposed to avoid implying a specific genesis. None is fully applicable to the features studied here because a variety of forms grade into each other as one moves along the climate gradient. Non-sorted circles grade into large turf-covered hummocks in the southern part of the Arctic, into non-sorted polygons, nets and small earth hummocks in the High Arctic, and into sorted patterns where there are coarse materials. Because no single term fully describes this range of variation, we retain the term 'frost boil' to apply to the range of small frost-heave features studied in this paper.

\section{METHODS}

\section{Locations and Summer Warmth Indices}

Seven $10 \times 10-\mathrm{m}$ grids were constructed in zonal habitats along a Low Arctic climate gradient in Alaska
(Figure 2). All sites except for Howe Island are easily accessible from the Dalton Highway. Extensive snow, and ground-temperature data are available from most sites (Romanovsky and Osterkamp, 1995; Romanovsky and Osterkamp, 1997). One study site, Happy Valley, is located within a CALM grid, and the West Dock site is adjacent to another (Brown et al., 2000). Air temperature data were collected at each location at standard height using Campbell data loggers. The summer warmth index (SWI) (the sum of the monthly mean temperatures above freezing $\left({ }^{\circ} \mathrm{C}\right.$ mo)) is an integrated value for the total amount of summer warmth available for plant growth. This index has been used to describe the northern limits of arctic plant-species distributions (Young, 1971). It is highly correlated with thawing degree-days (TDD), which is the sum of the daily mean temperatures greater than $0^{\circ} \mathrm{C}$. SWI is used for broad regional comparisons because it can be easily derived from monthly mean summaries. Howe Island and West Dock are in Bioclimate Subzone C; Deadhorse, Franklin Bluffs, and Sagwon MNT are in Subzone D; and Sagwon MAT and Happy Valley are in Subzone E. The summer warmth indices at these sites were 9.3, 14, 19.27, 28.2, 28.2 , and $30.2^{\circ} \mathrm{C}$ mo, respectively. 


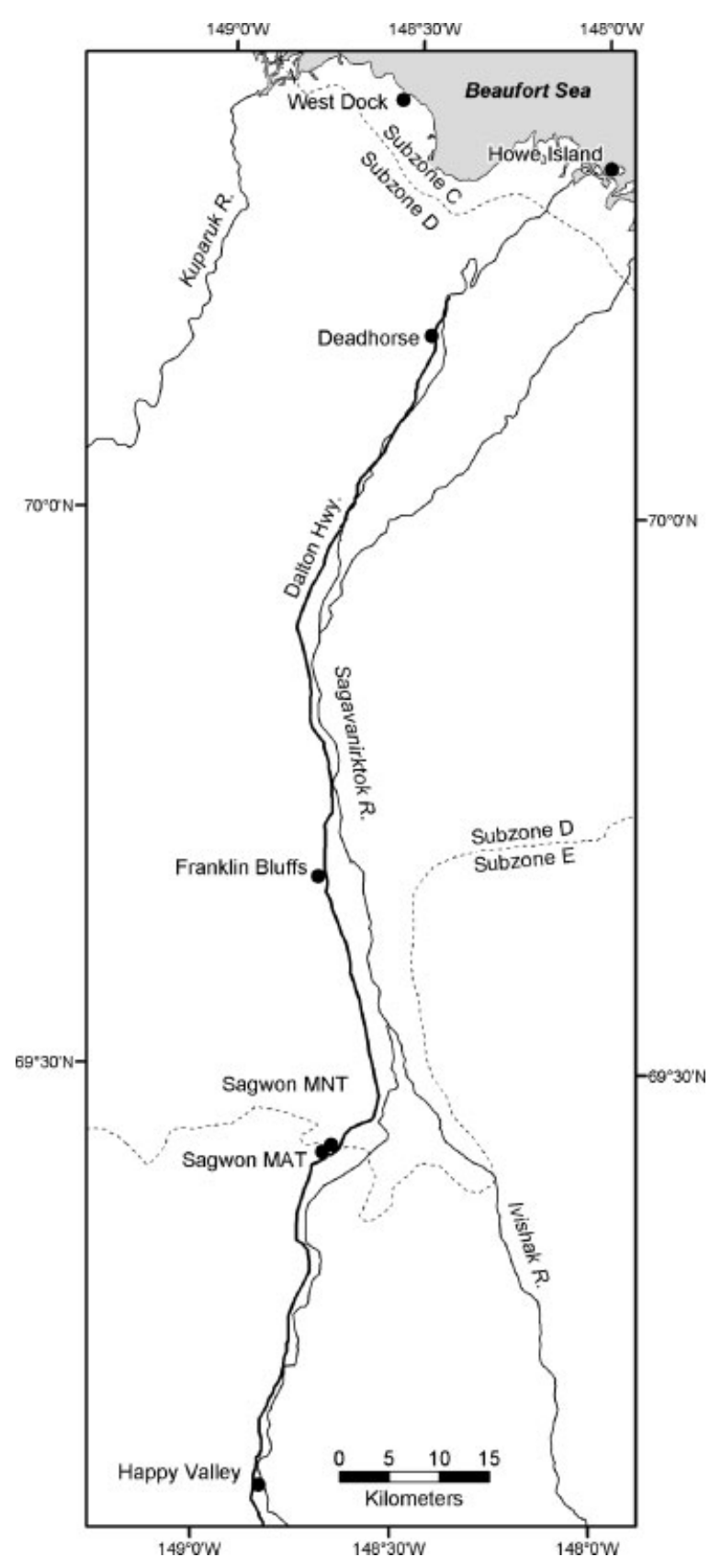

Figure 2 Locations of study grids along the Dalton Highway, northern Alaska. The approximate boundaries between bioclimate subzones $\mathrm{C}$ and $\mathrm{D}$ and between $\mathrm{D}$ and $\mathrm{E}$ are shown.

\section{Vegetation}

Aerial photographs were taken of each grid from a helicopter at approximately 50-m altitude. The vegetation was mapped on aerial photographs supplemented with plant-community and micro-site data collected from 441 points in each grid. Detailed studies of plant community composition were made using the BraunBlanquet relevé approach (Westhoff and van der Maarel, 1978). Vegetation was sampled in the grids and in nearby replicate plots. Biomass, leaf-area index, and the normalized difference vegetation index (NDVI) data were collected at each site along two 50-m transects located adjacent to the grids. Biomass data were collected from six $20 \times 50-\mathrm{cm}$ plots located at 5,25 and $45 \mathrm{~m}$ along the $50-\mathrm{m}$ transects. The samples were sorted in the field into plant functional types (shrubs, graminoids, forbs, mosses, lichens), and then later separated into woody, foliar, live and dead components. Leaf Area Index (LAI) was measured using a LI-COR LAI-2000 Plant Canopy Analyzer at 2-m intervals along the 50-m transects. The details of the biomass and LAI sampling methods are described in Walker et al. (2003).

NDVI is a unitless remotely-sensed index of vegetation green biomass that can be measured from earthorbiting satellites, aircraft, or with field instruments (Goward et al., 1985; Rouse et al., 1973). NDVI was used in this study to complement the biomass data, to give an index of the density of vegetation along the bioclimate gradient, and to contrast the abundance of vegetation on frost boils and inter-boil areas. The index is given by:

$$
\mathrm{NDVI}=(\mathrm{NIR}-\mathrm{R}) /(\mathrm{NIR}+\mathrm{R}),
$$

where NIR is the spectral reflectance in the nearinfrared band $(0.725-1.1 \mu \mathrm{m})$, dominated by light scatter from the plant canopy, and $\mathrm{R}$ is reflectance in the red $(0.58-0.68 \mu \mathrm{m})$, chlorophyll-absorbing portion of the spectrum (Markon, 1999). The index has been used extensively in tundra vegetation of northern Alaska as an indicator of biomass and other ecosystem properties such as $\mathrm{CO}_{2}$ flux (Hope et al., 1995; Hope et al., 1993; Jia et al., 2002; Jia et al., 2004; Shippert et al., 1995). The values can vary theoretically from 0 (no green vegetation) to 1.0 (very high cover of green vegetation).

Regional-scale NDVI was measured using AVHRR satellite-based time-series data for 1995-1999 (US Geological Survey (USGS) Alaska Data Center). These data were based on 14-day composite periods to match the processing of global data sets. We used the portion of the data between 1 April and 31 October, which brackets the snow-free period. Here we report maximum NDVI (MaxNDVI). We used 1:60000-scale color-infrared (CIR) aerial photographs (acquisition dates, 1978 and 1982) to delineate areas of homogeneous vegetation in the vicinity of the grids. This was a portion of the same data set used by 

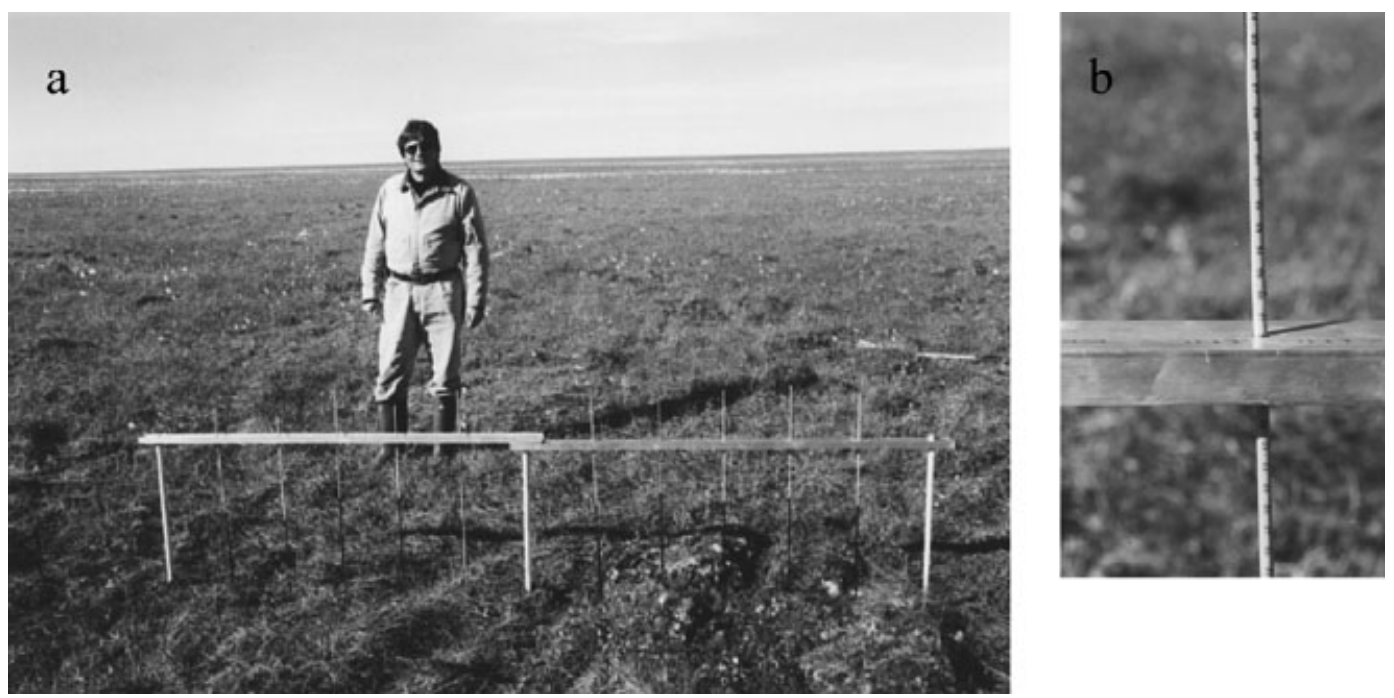

Figure 3 Heave instrument, Deadhorse, AK. (a) The horizontal bar is bolted to the vertical support members, which are deeply anchored in permafrost. (b) The thin vertical rods ride up and down with frost heave and settlement. Each bar is attached to a small foot that is buried just below the soil surface. Readings are periodically taken from each vertical rod.

Jia et al. (2002) for the analysis of intra-seasonal patterns of NDVI in relation to the climate record. Polygons were drawn around these areas on mylar transparent overlays. The aerial photographs and polygons were then digitized and geo-registered to the AVHRR imagery using ARC/INFO software. Details of the registration procedures are in Jia et al. (2002). MaxNDVI for each polygon was calculated from the set of annual maximum NDVI values for all pixels within the polygon. The integrated NDVI is the sum of all the biweekly NDVI values during the green period.

Plot-scale NDVI was measured to compare the density of vegetation on and between frost boils in subzones D and E. NDVI data were collected from frost boils and inter-boil areas using a hand-held PS-II portable field spectrometer made by Analytical Spectral Devices, Inc. The spectrometer measures reflectance in 256 channels. We grouped the data into the same red and near-infrared portions of the spectrum as those used for the AVHRR-derived NDVI values. Study plots were subjectively chosen as representative of typical frost boils and inter-frost-boil areas at each site. Data were collected from three frost-boil plots and three inter-boil plots at the Happy Valley, Sagwon MNT and Franklin Bluffs on 30 June 2002. Three replicate measurements were made on each plot.

\section{Thaw Depth and Frost Heave}

Thaw depths were measured on each of the $10 \times 10$-m grids during 14-16 August 2002. Measurements were made at 0.5 -m intervals ( 441 points in each grid) using a metal probe. Frost heave was monitored using the device shown in Figure 3. Each instrument measured heave at 10 points along a short transect traversing a representative frost boil and the adjacent inter-boil area. One heave instrument was located adjacent to each $10 \times 10$-m grid. At Happy Valley and Sagwon MAT, heave was measured on two types of frost boils: (a) large well-vegetated hummocks and (b) small barren inter-tussock frost boils. Maximum heave was recorded in mid-May of 2002 at all sites except Howe Island, where data were collected in May 2003. Base heave was recorded when the soils had thawed to their maximum thaw-layer thickness in late August.

\section{Soils}

Soil pits were excavated using shovels and a gaspowered jackhammer to a depth of $1 \mathrm{~m}$. One pit was dug at each site adjacent to the $10 \times 10$-m grid, such that the pit traversed a frost boil and inter-frost-boil area. Soil morphological properties were described according to the Soil Survey Manual (Soil Survey Staff, 1993). Soil samples from the genetic horizons were shipped to either the Palmer Research Center Laboratory or the National Soil Survey Laboratory (NSSL) for analysis. Soil pH values reported here were from the top mineral horizon using the saturated paste method with distilled water. Particle size was determined using the hydrometer method. Soil moisture was calculated on a volumetric basis (Gardner, 1986). Data reported are the average of three replicates from each soil. 


\section{RESULTS}

\section{Frost-Boil Morphology and Vegetation}

The vegetation maps of the grids are shown in Plate 1. The percentage cover of barren frost boils (hachured gray areas in Plate 1) declined southward from 25\% at Howe Island to $1 \%$ at Sagwon MAT and Happy Valley. The total of all vegetated and non-vegetated frost-boil habitat types declined from 25\% at Howe Island to 5\% at Sagwon MAT and 13\% at Happy Valley. The inter-boil areas and the vegetated frostboil habitat types had a corresponding increase in area. The West Dock site is not shown in Plate 1 because the vegetation was a continuous mat of moist tundra with no frost boils. This site had a thin organic mat that lay directly on a coarse sandy gravel alluvial material that was relatively unaffected by frost heave.

The morphology of the frost boils and species composition of the accompanying vegetation changed considerably along the temperature gradient (Table 1). At the northernmost site on Howe Island in Subzone $\mathrm{C}$, the frost boils had only a few widely scattered grasses (Puccinellia angustata) and forbs (Braya purpurascens) on large otherwise barren 1 to $2-\mathrm{m}$ patches of soil (see Figure 1 and Plate 1). Such large barren frost boils are uncommon along the Beaufort coast of northern Alaska and more similar to the frost boils that occur in the central portions of Subzone C, such as Banks, Victoria, and other islands of the Canadian Archipelago. Crustose lichens were dominant in dry microsites surrounding the frost boils (see Table 1 for species). A continuous cover of vegetation consisting of prostrate shrubs, forbs, and mosses occurred in the relatively moist micro-sites in troughs of ice-wedge polygons.

Within Subzone D, there was a gradual southward diminishment of the cover of bare soil on the frost boils (Table 1 and Plate 1). The relatively barren portions of the frost boils had a distinctive plant association composed of scattered herbaceous plants, small mosses and liverworts, and soil lichens (see Table 1 for species). Many of the common species are calciphiles, such as the vascular plants Saxifraga oppositifolia, Dryas integrifolia, Cardamine hyperborea, Senecio atropurpureus, and Tofieldia coccinea, the small mosses Catascopium nigritum, Ditrichum flexicaule, and Distichium capillaceum, and soil lichens Cladonia poccillum and Lecanora epibryon. More stable portions of the frost boils had a plant association consisting of prostrate dwarf-shrubs, many herbaceous plants, a thin layer of mosses less than $3 \mathrm{~cm}$ thick, and many lichens. Inter-boil areas in Subzone D consisted of plant communities of the association Dryado integrifoliae-Caricetum bigelowii (Walker et al., 1994) that also occurred on non-acidic mesic uplands and hill slopes. Moss carpets in the inter-boil areas thickened toward the south and formed mats in excess of $10 \mathrm{~cm}$ near the Subzone E boundary. Areas with somewhat wetter soils had rings of tussock cottongrass (Eriophorum vaginatum) around the margin of the frost boils.

In tussock-tundra areas of Subzone E at Sagwon MAT and Happy Valley, the frost boils had two distinctive forms. The first were small, $20-30-\mathrm{cm}$ diameter barren patches that were widely scattered and occurred in depressions between cottongrass tussocks (note small hachured gray areas in the maps of Sagwon MAT and Happy Valley, Plate 1). These were often wet sites with few vascular plants and a thin layer of cryptogamic plant species, mostly liverworts (see Table 1 for species). Also in Subzone E, large well-vegetated raised hummocks occurred on stabilized frost boils (hachured orange areas in maps of Plate 1; see Figure 10). These features were $1-1.5 \mathrm{~m}$ in diameter and about $30-50 \mathrm{~cm}$ high. The hummocks had vegetation that was somewhat drier than the surrounding tussock tundra with complete vegetative cover consisting of sedges, acidiphilic dwarf shrubs, mosses, and abundant lichens. The inter-boil areas consisted of the tussock tundra plant association Sphagno-Eriophoretum vaginati (Walker et al., 1994).

Biomass, LAI, and NDVI increased toward the south in response to the warmer summer temperatures (Table 2). A five-fold increase in total biomass occurred along the gradient $\left(183 \mathrm{~g} \mathrm{~m}^{-2}\right.$ at Howe Island and $932 \mathrm{~g} \mathrm{~m}^{-2}$ at Sagwon MAT, Table 2). A large increase in shrub biomass occurred at the Subzone DE boundary, with generally less than $100 \mathrm{~g} \mathrm{~m}^{-2}$ of shrubs north of the boundary and more the $250 \mathrm{~g} \mathrm{~m}^{-2}$ south of the boundary. LAI of the plant material above the moss layer also showed a major increase from values less than 0.9 south of the boundary to about 1.5 south of the boundary.

MaxNDVI increased from 0.259 at Howe Island to 0.534 at Sagwon MAT and 0.527 at Happy Valley, and the integrated NDVI increased from 1.42 at Howe Island to 4.23 at Sagwon MAT. The NDVI values were not measured directly on the grids but were measured from large homogeneous areas of tundra in the immediate vicinity of the grids, and indicate that the greenness of large landscapes in the vicinity of the grids increased toward the south.

There were no data to directly compare the biomass on frost boils vs. inter-boil areas. The biomass data cited above were from randomly selected sites, and were thus average landscape biomass values. 
Table 1 Frost-boil morphology and typical plant species growing on frost boils in subzones C, D and E, northern Alaska.

\begin{tabular}{lll}
\hline Subzone & Frost-boil morphology & Frost boils \\
\hline C (Howe & Large barren circles, & Very scattered grasses and \\
Island) & $1-2 \mathrm{~m}$ diameter, & forbs (including Pucccinellia \\
& 20 circles per $100 \mathrm{~m}^{2}$ & angustata, Braya purpurascens)
\end{tabular}

D (Deadhorse, Partially vegetated Franklin Bluffs, circles, with some Sagwon MNT) areas of barren soil, $1-1.5 \mathrm{~m}$ diameter, $15-20$ circles $/ 100 \mathrm{~m}^{2}$

$\begin{array}{ll}\text { E (Sagwon } & \text { Two types: } \\ \text { MAT, Happy } & \text { a. Scattered small } \\ \text { Valley) } & \text { barren patches } \\ & \text { 20-30 cm diameter } \\ & \text { located between }\end{array}$

\section{Mosaic consisting of:}

Active barren patches: scattered basiphilous herbaceous plants (including Antennaria friesiana, Cardamine hyperborea, Carex capillaceum, C. membranacea, Eriophorum angustifolium/triste, Juncus biglumis, Minuartia rossii, Polygonum viviparum, Saxifraga oppositifolia, Senecio atropurpureus, Tofieldia coccinea), small mosses and liverworts (including Aneura pinguis, Bryum wrightii, Catascopium nigritum, Didymodon icmadophylos, Distichium capillaceum, Encalypta rhaptocarpa, Tortella tortuosa), and soil lichens (Cladonia pocillum, Collema sp., Lecanora epibryon, Mycolimbia lobulata, Polyblastia sendtneri, Rinodina roscida, Solorina bispora).

More stable patches: plant association consisting of prostrate dwarf shrubs (Dryas integrifolia, Salix reticulata), many herbaceous plants (including Astragalus umbellatus, Cardamine hyperborea, Carex membranacea, $C$. scirpoidea, Eriophorum triste, Lupinus arcticus (toward the south), Minuartia rossii, Pedicularis capitata, P. lanata, Polygonum viviparum, Rhododendron lapponicum (toward the south), Senecio atropurpureus, Tofieldia coccinea), a thin layer of mosses less than $3 \mathrm{~cm}$ thick (including Distichium capillaceum, Ditrichum flexicaule, Rhytidium rugosum, Sanionia uncinatus, Tomentypnum nitens), and many lichens (including Cetraria islandica, Cladonia poccillum, Dactylina arctica, Flavocetraria cucullata, F. nivalis, Thamnolia spp.)

a. Few vascular plants (Juncus biglumis, Luzula arctica) and a thin layer of cryptogamic plant species, mostly liverworts (including Anthelia juratzkana, Cephalozia bicuspidata, Cryptocolea imbricata, Diplophyllum sp., Jungermannia sp.,
Inter-boils

Dry microsites: Mostly crustose lichens (including Fulgensia bracteata, Lecanora epibryon, Mycobilimbia lobulata, Polyblastia sendtneri).

Moist microsites: Continuous cover of vegetation consisting of prostrate shrubs (Dryas integrifolia, Salix arctica, Salix ovalifolia), forbs (including Artemisia borealis, Cerastium beeringianum, Chrysanthemum integrifolium, Cochlearia officinalis, Draba alpina, Melandrium apetalum, Minuartia arctica, Pedicularis neoalaskanum, Polygonum viviparum, Saxifraga oppositifolia), and mosses (including Amblystegium serpens, Ctenidium procerrimum, Ditrichum flexicaule, Distichium capillaceum, Tortula ruralis, Tomentypnum nitens).

Association Dryado integrifoliaeCaricetum bigelowii (M.D. Walker et al., 1994). The dominant plants are sedges (including Carex bigelowii, $C$. membranacea, Eriophorum triste), dwarf shrubs (Cassiope tetragona, Dryas integrifolia, Salix arctica, Rhododendron lapponicum (toward the south), $S$. richardsonii, $S$. reticulata), and mosses (including Aulacomnium turgidum, Catascopium nigritum, Distichium capillaceum, Ditrichum flexicaule, Hylocomium splendens, Tomentypnum nitens) and a few lichens (including Cetraria islandica, Dactylina arctica, Flavocetraria cucullata, F. nivalis, Peltigera aphthosa, P. canina, Thamnolia spp.)

a. Association Sphagno-Eriophoretum vaginati (M.D. Walker et al., 1994). This association consists of tussock cottongrass (Eriophorum vaginatum), dwarf shrubs (including Betula nana, Empetrum

(Continues) 


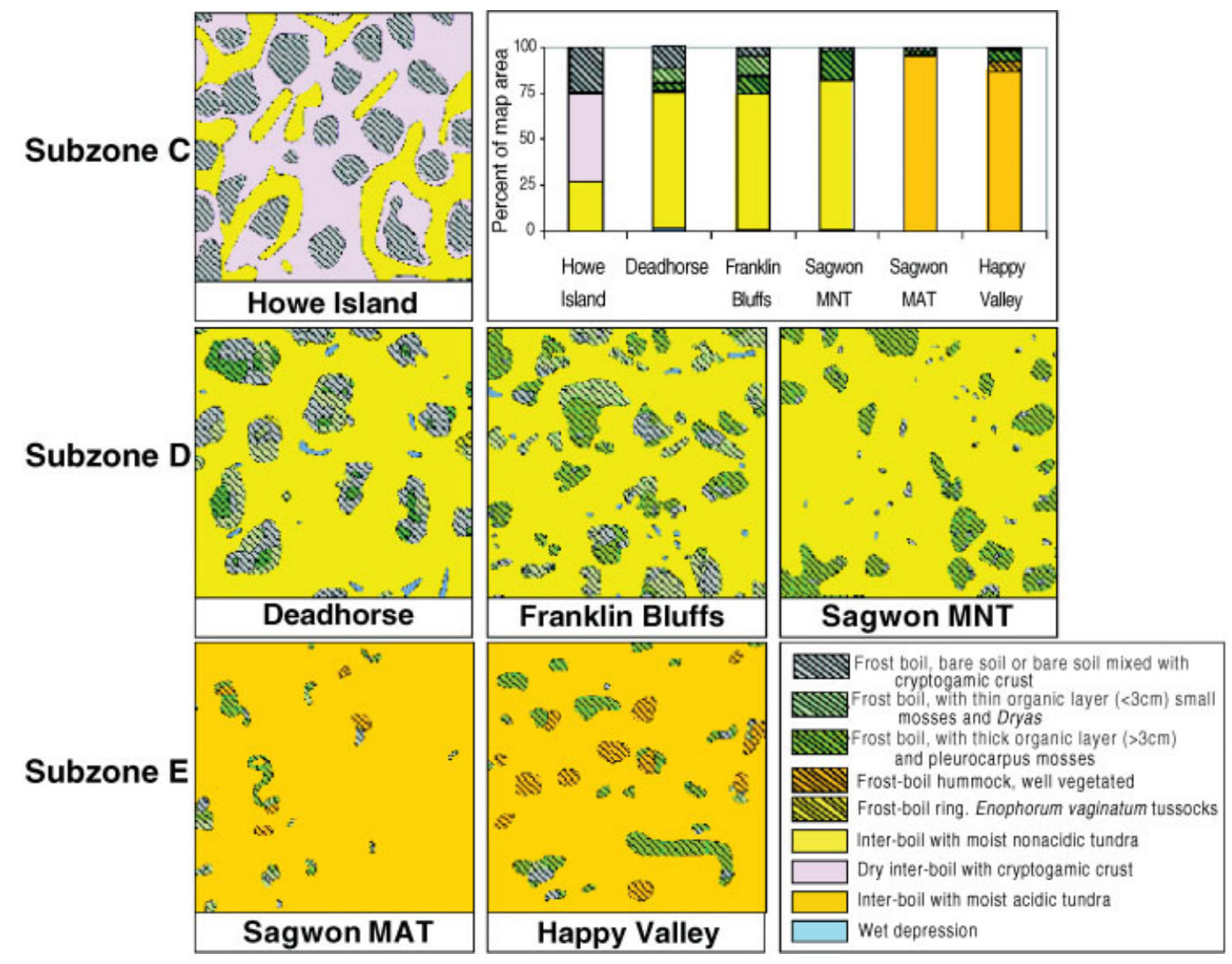

Plate 1 Vegetation/habitat types associated with frost boils on $10 \times 10$-m grids at six sites along the bioclimate gradient near the Dalton Highway. Note the trend of less bare soil with warmer summer temperatures (toward the right and down). Also note the frost-boil hummocks in Subzone E. 


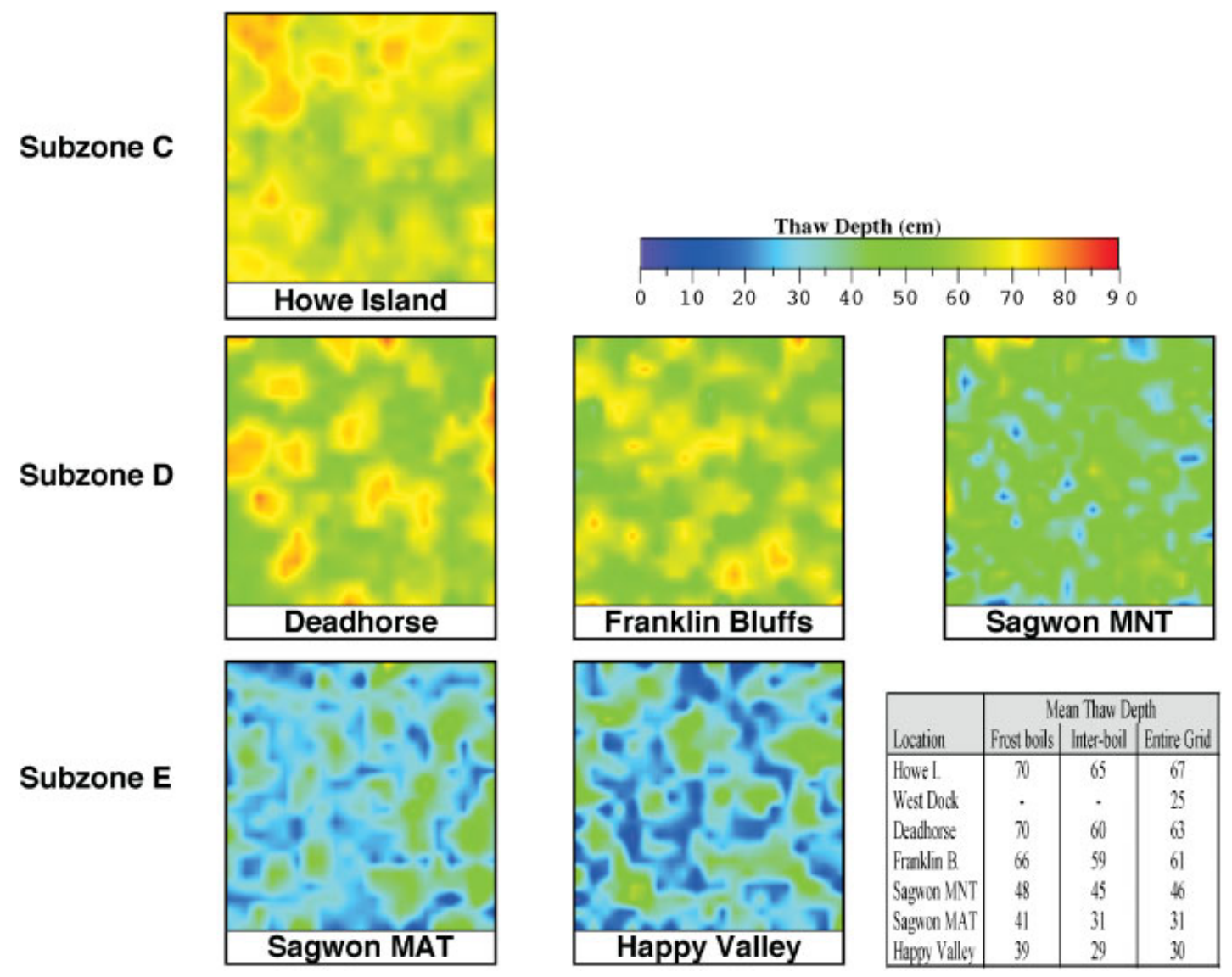

Plate 2 Maps of thaw layers in the $10 \times 10$-m grids, northern Alaska, August 2002. West Dock is not shown because there were no frost boils at that site. 
Table 1 Continued.

\begin{tabular}{|c|c|c|c|}
\hline Subzone & Frost-boil morphology & Frost boils & Inter-boils \\
\hline & $\begin{array}{l}\text { cottongrass tussocks. } \\
5-10 \text { patchs } / 100 \mathrm{~m}^{2}\end{array}$ & $\begin{array}{l}\text { Lophozia spp., Sphenolobus minutus), mosses } \\
\text { (including Dicranella subulata, Hylocomium } \\
\text { splendens, Pohlia crudoides), and few lichens } \\
\text { (including Arthrorhaphis sp., Cetraria } \\
\text { cucullata, Cladonia fimbriata, C. coccifera, } \\
\text { C. chlorophaea, Dactylina ramulosa, Peltigera } \\
\text { aphthosa, P. rufescens). }\end{array}$ & $\begin{array}{l}\text { nigrum, Ledum decumbens, Rubus } \\
\text { chamaemorus, Salix pulchra, Vaccinium } \\
\text { vitis-idaea, V. uliginosum), mosses } \\
\text { (including Sphagnum spp., Aulacomnium } \\
\text { turgidum, Dicranum spp., Hylocomium } \\
\text { splendens, Polytrichum strictum), and } \\
\text { scattered lichens (including Cetraria } \\
\text { islandica, Cladina arbuscula, C. mitis, C. } \\
\text { rangiferina, Cladonia amaurocraea, } \\
\text { Flavocetraria spp., Peltigera spp.) }\end{array}$ \\
\hline & $\begin{array}{l}\text { b. Large hummocks, } \\
20-30 \mathrm{~cm} \text { high and } \\
1-1.5 \mathrm{~m} \text { diameter, } \\
5-10 \text { hummocks/ } \\
100 \mathrm{~m}^{2}\end{array}$ & $\begin{array}{l}\text { b. Vegetation somewhat drier than the } \\
\text { surrounding tussock tundra with complete } \\
\text { vegetative cover consististing of sedges } \\
\text { (mainly Carex bigelowii), grasses (Arctagrostis } \\
\text { latifolia), acidiphilous dwarf shrubs (Betula nana, } \\
\text { Ledum decumbens, Vaccinium vitis-idaea), mosses } \\
\text { (including Aulacomnium turgidum, Dicranum } \\
\text { elongatum, Hylocomium splendens, Racomitrium } \\
\text { lanuginosum, Pleurozium schreberi), and } \\
\text { abundant lichens (including Cetraria spp., } \\
\text { Cladina mitis, C. stygia, Cladonia chlorophaea, } \\
\text { Dactylina arctica, Nephroma arcticum, Peltigera } \\
\text { spp.) }\end{array}$ & b. Same as inter-boil areas of a. \\
\hline
\end{tabular}

However, ground-level measurements of NDVI and LAI were collected from frost boils and inter-boil areas at three sites, Happy Valley, Sagwon MNT, and Franklin Bluffs (Figure 4). These data provide some impression of the green biomass on frost boils compared to inter-boil areas across the Subzone D/E boundary (see Figure 2). Across all three locations, the average ground-level NDVI on the frost boils was 0.41 , and the average LAI was 0.19 , whereas the interboil areas had an average NDVI of 0.54 and an LAI of

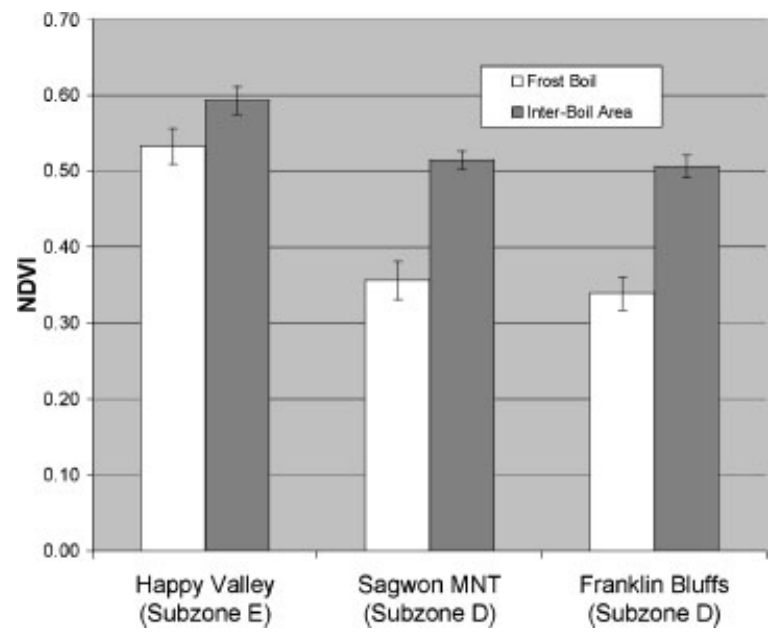

Figure 4 NDVI (mean and standard error) measured on frost boils and inter-boil area at three sites, $25 \mathrm{Jul}$ 2002, northern Alaska.
0.88. The NDVI was much higher at the Happy Valley Subzone E site, particularly on the frost boils because of the much denser cover of plants on the Subzone E frost boils.

\section{Thaw Depth and Frost Heave}

The least thaw was recorded in Subzone C, at the coastal West Dock site $(25 \mathrm{~cm})$ (see Table insert in Plate 2). However, this site had no frost boils. Sites with frost boils showed a trend of thinner thaw layers inland from the coast. The deepest thaw occurred at Howe Island, where the average thaw was $70 \mathrm{~cm}$ within the frost boils, and $65 \mathrm{~cm}$ in the inter-boil areas. The least thaw occurred at Happy Valley, $39 \mathrm{~cm}$ in the frost boils and $29 \mathrm{~cm}$ between frost boils.

Thaw-depth maps give a better indication of frost boil locations than vegetation maps. For example, at Happy Valley and the Sagwon MAT sites, the map of the thaw depths (Plate 2) shows the presence of a thaw pattern similar to that in areas with abundant frost boils, whereas the vegetation maps show little surface indication of frost boils because most are completely covered with vegetation. This is not to suggest that all areas have a subsurface pattern of frost boils. Frost boils are generally associated with fine- and mediumtextured soils, and are uncommon in coarse-textured sandy and gravelly soils. For example, the West Dock site had near-surface gravels and no surface expression of frost boils, and thaw likewise did not vary much. 


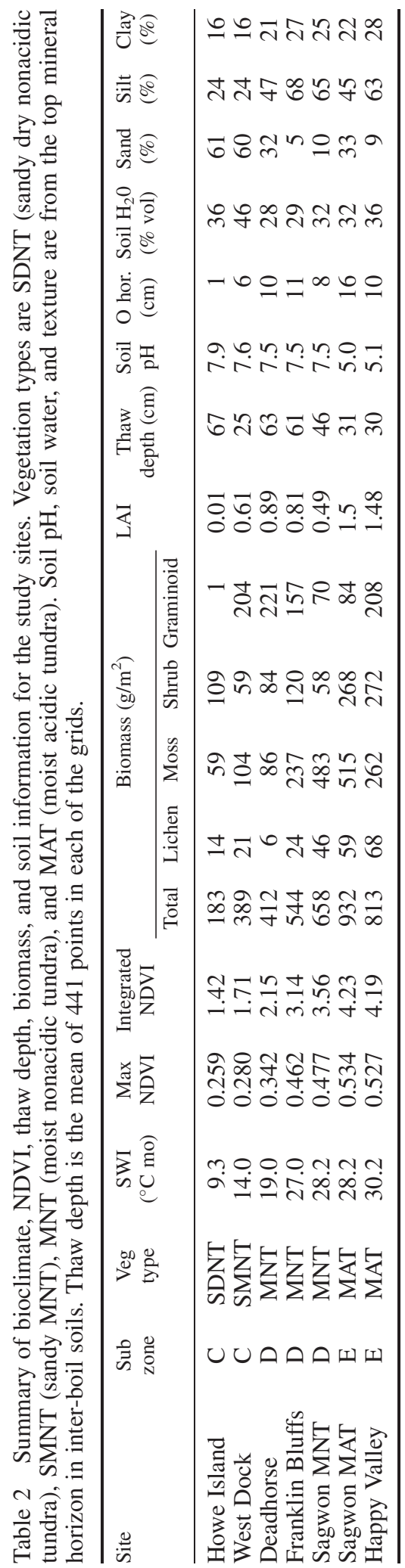

Frost heave varied from less than $1 \mathrm{~cm}$ at the West Dock site to $20 \mathrm{~cm}$ on frost boils at Deadhorse (Figure 5). Heave on the frost boils with silt-loam to loamy soils was $9-20 \mathrm{~cm}$ versus only $4 \mathrm{~cm}$ in the sandy loam soil at Howe Island. Heave in the interboil areas varied from $3 \mathrm{~cm}$ at Howe Island to $5 \mathrm{~cm}$ at the Sagwon MNT site. The soil at West Dock had only slight heave. Differential heave (the difference between the heave on the frost boil and inter-boil areas) was greatest at Deadhorse and Franklin Bluffs $(17 \mathrm{~cm})$. The least differential heave occurred at West Dock $(0 \mathrm{~cm})$ and Howe Island $(1 \mathrm{~cm})$, sites with relatively sandy soils.

The low amount of heave in the frost boils on Howe Island occurred on the site with the most clearly expressed frost boils (Figure 1). Why such a small amount of heave has such a large effect on the vegetation is not clear. One possible explanation is that the barren frost boils in colder environments have higher salt concentrations (Michaelson, unpublished data). The barren frost boils typical of coastal areas are apparently pumping salt to the surface because of relatively high evaporation. Salt has been shown to be particularly toxic to Dryas, the dominant plant in Subzone C zonal sites (Simmons et al., 1981), and may have similar effects on other typical tundra species. The two species of vascular plants found growing in the barren frost boils at Howe Island, Puccinellia angustata and Braya purpurascens, are both salt-tolerant species commonly found in dry disturbed saline coastal habitats at Prudhoe Bay.

There was no relationship between air temperature and soil heave. The large difference in heave between the frost boils and the inter-boil areas appears to result from a combination of factors, The thicker thaw layer of the frost boils probably allows more ice lensing to develop, resulting in more heave. However, the

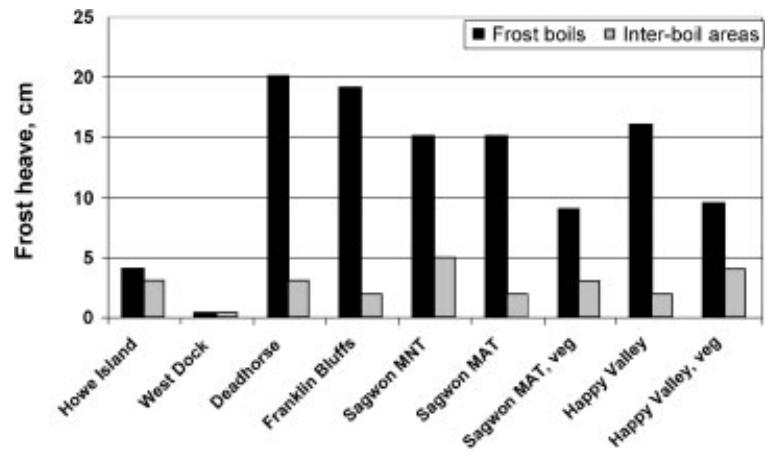

Figure 5 Maximum heave on frost boils and inter-boil areas, northern Alaska, 2001-2002, except for Howe Island, which was measured in 2002-2003. 
difference in the amount of heave between the frostboil and inter-boil areas cannot be explained completely by differences in thaw-layer thickness alone. Cryosuction probably pulls water from the inter-boil areas to increase the amount of heave within the frost boil, as explained in the differential-frost-heave model (Peterson and Krantz, 2003).

\section{Soils}

Soil $\mathrm{pH}$, organic horizon thickness, soil moisture, and texture are shown in Table 2. Soil pH was high at the northern end of the gradient in subzones $\mathrm{C}$ and $\mathrm{D}$ (7.97.5), and low at the southern end of the gradient in Subzone E (5.0-5.1). Organic soil horizons were 1$6 \mathrm{~cm}$ in Subzone C, $8-11 \mathrm{~cm}$ in Subzone D and 10$16 \mathrm{~cm}$ in Subzone E. Volumetric soil moisture varied between 28 and $46 \%$, but showed no major trend across the transect. Soil textures were sandy loams at Howe Island and West Dock, silt loams at Franklin Bluffs and Sagwon MNT, and loams at Deadhorse, Sagwon MAT, and Happy Valley. Other observations important to our conceptual model of frost-boil formation are summarized here.

1. Most frost-boil soils exhibit a platy structure that crumbles to a granular structure. This is the result of ice-lenses and veins that form during the winter (Fowler and Krantz, 1994; Gilpin, 1980) (Figure 6).

2. The lowest part of several soil profiles exhibited a zone termed the intermediate layer (Shur, 1988). The cryogenic structure of this zone consists of a continuous matrix of ice containing blocks of soil aggregates (Figure 7).

3. Soil properties vary considerably across frost boils (Figure 8). Nutrient concentrations and water content decline and the bulk density increases from the margin toward the center in response to more active, less vegetated soils near the center of the frost boils. As one moves from the coast inland, the soils on frost boils become more vegetated. Within Subzone E, the frost boils are completely vegetated, and form hummocks that have well developed organic soil horizons (Figure 9).
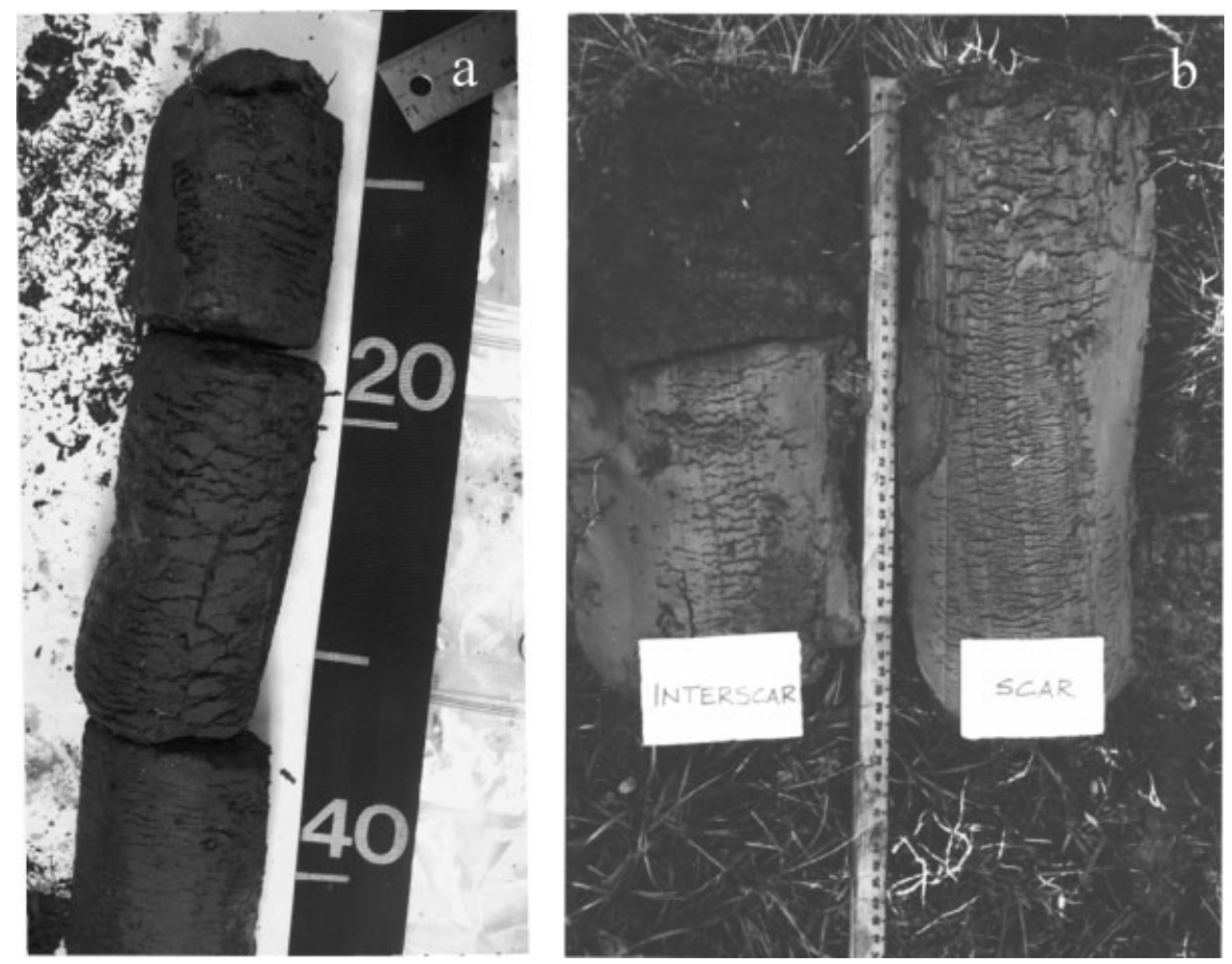

Figure 6 Ice lenses in frost-boil soils. (a) Soil core taken from a frost boil in winter 2002 at the Franklin Bluffs site. Dark-colored veins are ice lenses 1-3 mm thick. The lenses are thicker at the top of the core and thin toward the bottom. (b) Soils taken in summer from an interfrost-boil area (left) and a frost boil (right). The platy structure of the soil is the result of ice lenses that were present during the winter. Note the dark $20-\mathrm{cm}$ thick organic layer above the mineral portion of the inter-frost-boil soil. 


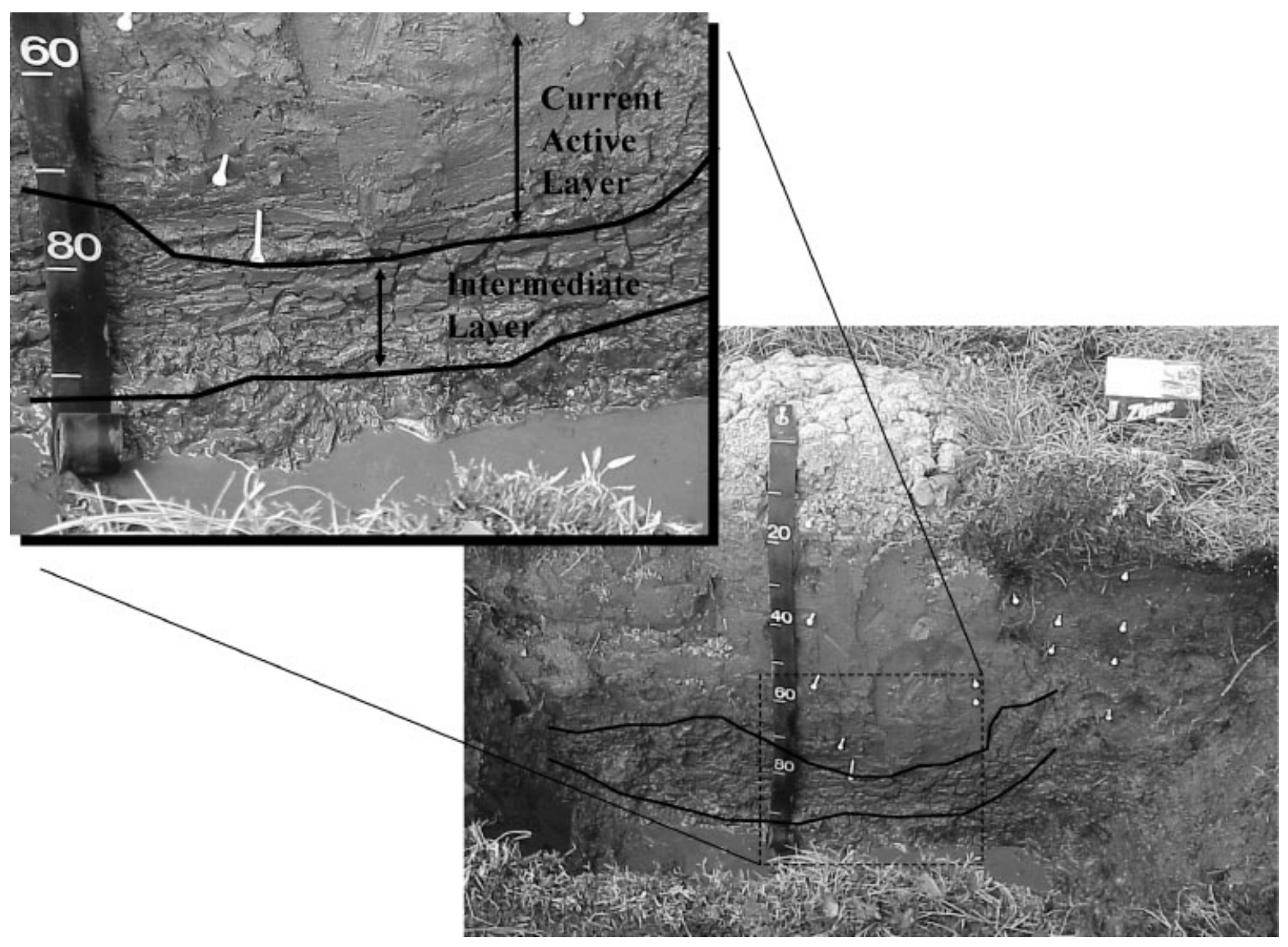

Figure 7 Soil pit traversing a frost boil and inter-boil area, showing the structure of the soil at the top of the permafrost table. Soil below the active layer was exposed with a jackhammer. Note the reticulate pattern of horizontal ice lenses and vertical veins in the ice-rich intermediate layer. The darker color of the intermediate layer is caused by high organic matter content.

\section{DISCUSSION}

\section{The Relationship of Vegetation to Patterned-Ground Morphology}

One of the most intriguing aspects of frost boils is their regular pattern (Figure 1). Models of self-organization of frost boils have been presented for sorted forms (Kessler et al., 2001; Kessler and Werner, 2003), and non-sorted forms (Peterson and Krantz, 2003; Peterson et al., 2003). The Peterson and Krantz differentialfrost-heave (DFH) model is appropriate for finegrained sediments in northern Alaska. The model is based on differential frost-heave processes and predicts order of magnitude heave and spacing of frost boils and can account for the circular motion of soils within frost boils. It is an inception model that describes initiation of frost boils in homogeneous soils.

The most thorough analysis of the relationship between ecosystems and frost boils to date is that of
Nadezhda Matveyeva (Chernov and Matveyeva, 1997; Matveyeva, 1998). She described the trends of horizontal and vertical structure of the vegetation in frost boil systems, and developed a concept of succession associated with frost boils occurring on the Taimyr Peninsula. Similar relationships with respect to bioclimate zonation have been verified in North America (Gould et al., 2003). The major elements of Matveyeva's zonal scheme are summarized in Figure 10. The names of Matveyeva's subzones have been modified to show relationships to the circumpolar arctic vegetation map (CAVM Team, 2003).

In Subzone A, the coldest regions of the extreme High Arctic (in the sense of Polunin (1951)), nearly barren, small non-sorted polygons approximately $20 \mathrm{~cm}$ in diameter form due to desiccation and/or seasonal frost cracking (Figure 10). Small mosses and lichens fill some of the cracks.

In Subzone B, some of the cracks widen, possibly due to preferential thermal cracking at these sites, 


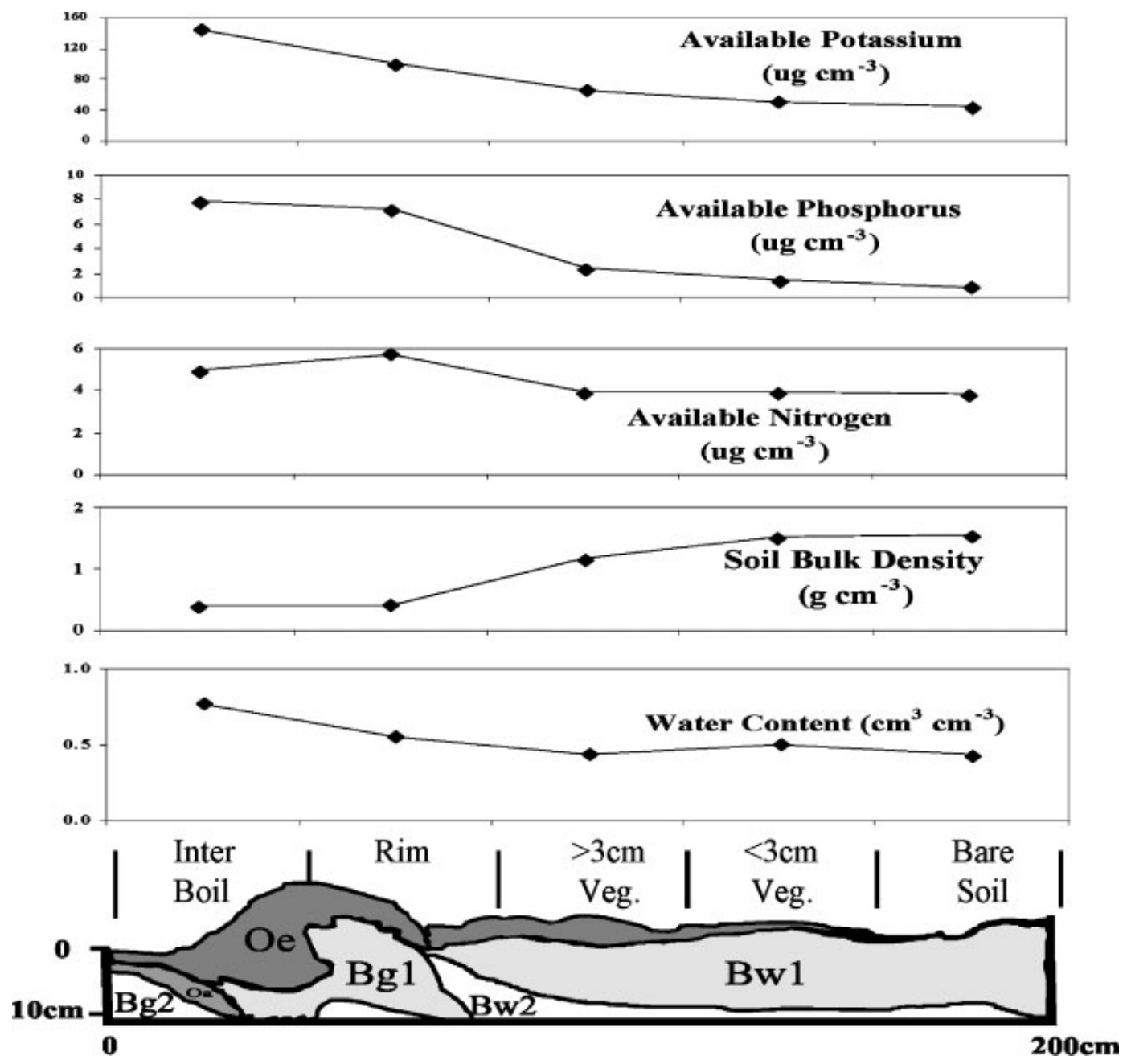

Figure 8 Spatial variation in soil properties across a frost boil. Data are from a frost boil at the Deadhorse site.

forming well-developed hummocks with a diameter of about 1-2 m. Distinct troughs between the hummocks are filled with a mix of herbaceous and cryptogam plants. The tops of the hummocks are sparsely vegetated and have desiccation features and smaller hummocks.

The best-developed frost-boils occur in the 'typical tundra' of Matveyeva, which is the southern portion of the Middle Arctic and the northern portion of the Low Arctic of Polunin, more or less equivalent to subzones $\mathrm{C}$ and D in Figure 10. Landscapes with frost boils in this region are called spotted tundra in the Russian literature (Alexandrova, 1980). In Subzone C, frost boils are predominantly barren. The diameter of the barren frost boils is $1-3 \mathrm{~m}$. Inter-boil areas are well vegetated, but generally have thin moss carpets.
In Subzone D, the vegetation on the frost boils is more active, forming distinct zonation on the frost boils with areas of bare soil and some areas with thin cryptogam and vascular-plant cover. Areas between the frost boils are very well vegetated with thicker moss carpets.

In Subzone E, the frost boils are often completely covered with vegetation. The moss layer and organic soil horizons are thinner than in the inter-boil area. Thick vegetation mats often completely mask the frost boils, and sometimes the vegetation forms hummocks or mounds $1-2 \mathrm{~m}$ in diameter on old inactive frost boils. Soils in portions of the mounds can be reexposed through heaving or other disturbance, but these areas are quickly re-vegetated. Matveyeva considers the series in Figure 10 to also be a succession 


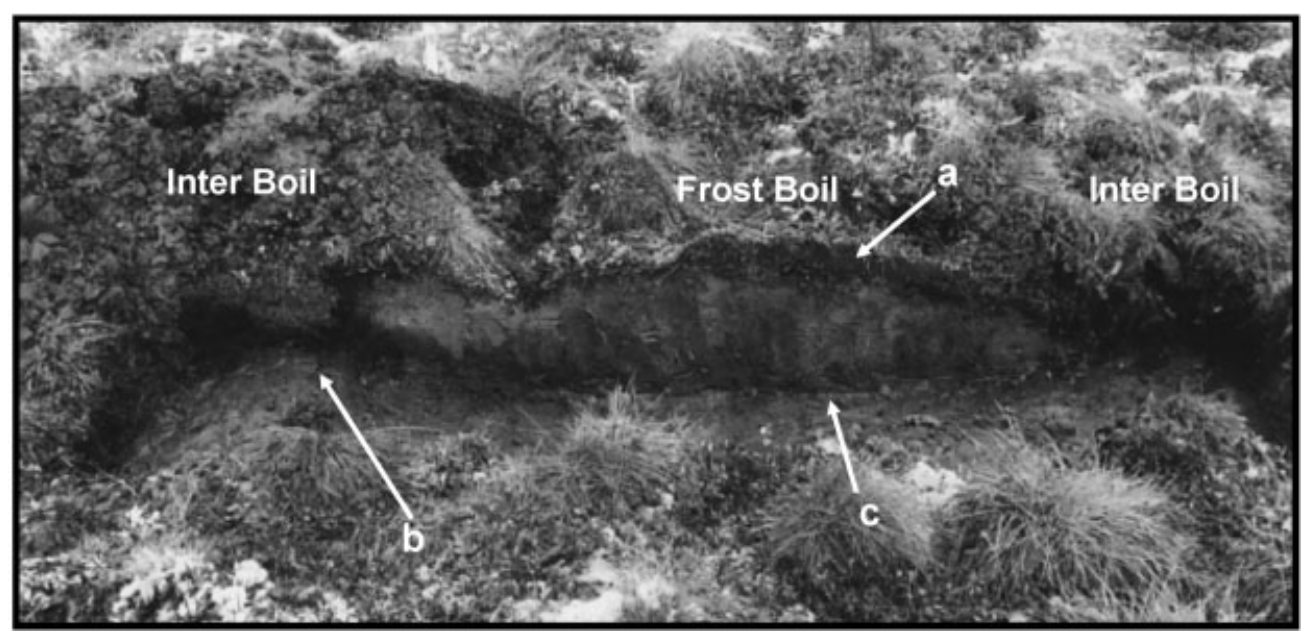

Figure 9 Soil trench across a vegetated frost boil hummock at the Sagwon MAT site (Subzone E). The trench extends to the base of the thaw layer. Note: (a) the well vegetated frost-boil surface and 8-cm thick dark-colored A/O soil horizon, indicating a long stable period; (b) the rise in the permafrost table, the shallow active layer $(20 \mathrm{~cm})$, and the lack of a mineral horizon in the inter-boil areas; and (c) and relatively thick active layer $(40 \mathrm{~cm})$ and saucer-shaped depression in the permafrost beneath the frost boil.

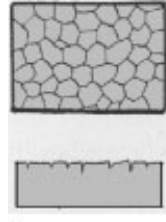

A
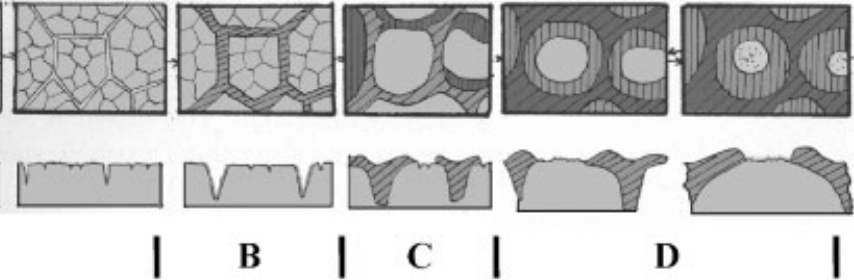

Bioclimate subzones
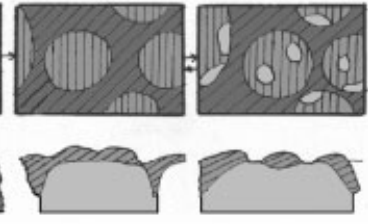

$\mathbf{E}$

Figure 10 Patterned-ground forms along the Arctic bioclimate gradient. (Adapted from Chernov and Matveyeva (1997, Fig. 16.51) Modified to show the trends with respect to bioclimate subzones of the Arctic vegetation map (CAVM Team, 2003).

sequence, so frost boils typical of colder subzones can occur in warmer subzones because of local disturbance factors or non-zonal site conditions. A more complete description of the zonal trends of patterned ground morphology and vegetation can be found in Chernov and Matveyeva (1997).

\section{Effects of Heave and Vegetation on Frost-Boil Soils}

Frost boils are normally associated with fine and medium textured soils in ice-rich permafrost regions. The silty and loamy soils of northern Alaska are ideal for frost-boil formation. In such soils, the center portion of a frost boil is elevated in winter with the growth of ice lenses (Figure 11). In summer, viscous relaxation occurs and the frost boil settles back toward its previous position. The soils, however, do not settle completely back each year, and over time, net upward particle trajectories occur in the center of the frost boil (Peterson et al., 2003). At the surface of the frost boil, particle trajectories are outward from the center due to soil creep, and then downward around the margins of the frost boil. Well-developed organic soil horizons develop in the undisturbed inter-boil areas. Particles and dissolved organic material are carried downward at the margins of the frost boil by soil movement and leaching. Organics accumulates in the thawed bowl at the base of the frost boil. Toward the center of the frost boil, particle trajectories are upward, and some organic material from the base of the thaw layer is carried upward, where it is acted on by biological activity to release nitrogen and minerals for plant uptake, and $\mathrm{CO}_{2}$ to the atmosphere (Figure 11). The vertical motion of material within the frost boil is apparently a slow process, requiring one or more centuries for one cycle (Peterson et al., 2003). No radiocarbon dates are currently available from our frost boils, but dates from Canadian mud boils suggested average movement rates of less than $1 \mathrm{~mm} \mathrm{y}^{-1}$ for subducted organic matter on three frost boils of the 


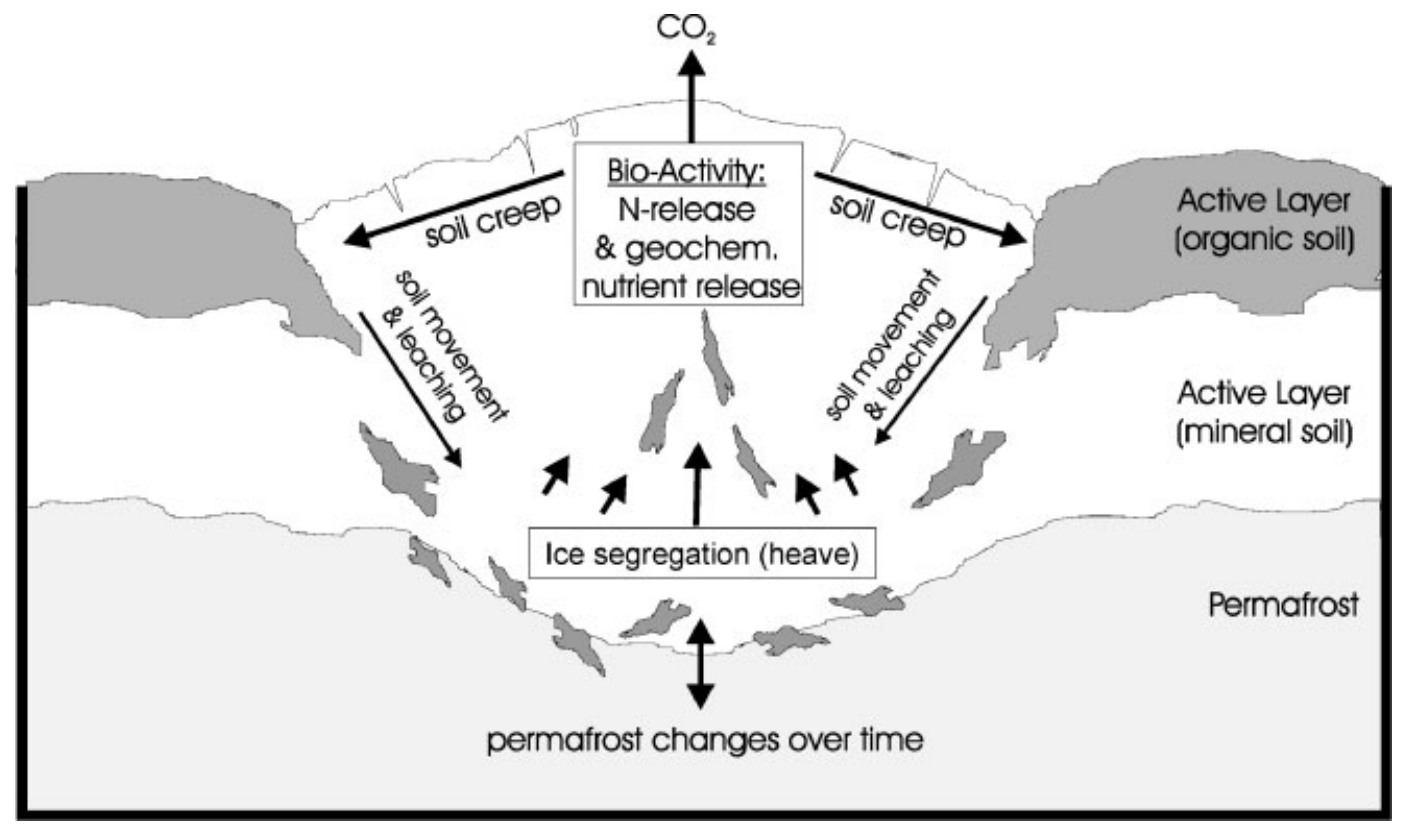

Figure 11 Conceptual diagram of biogeochemical cycling within frost boils. See text for explanation.

Boothia Peninsula (Dyke and Zoltai, 1980). These very slow rates indicated that the frost boils had been in place for several millennia.

The intermediate zone (see Figure 7) reflects periodic and directed changes in the thaw-layer thickness (Shur, 1988). The permafrost table is aggrading partly because loess and organic matter continue to accumulate on the soil surface and partly because the thickness of the thaw layer is decreasing as the site becomes more vegetated (Ping et al., 2002). Soil heat flux is reduced due to the insulation effect of the vegetation layer (Ping et al., 2002) (see Figure 6b). Studies in northern Yakutia have shown that the vegetation mat also affects the intermediate layer. Shur (1988) found that the intermediate layer was less developed near the shore of the Arctic Ocean than in areas $100-200 \mathrm{~km}$ inland where the vegetation is more active. Our comparisons of the intermediate layer in Arctic Alaska show similar large differences in ice content and cryogenic structure.

\section{A Conceptual Model of Frost-Boil Formation Along a Climate Gradient}

Based on our observations from Alaska, some reconnaissance studies in Canada, and information from the literature, we have formed a general hypothesis regarding climate-frost-boil interactions. A simple conceptual model of the frost-boil system on zonal sites is shown in Figure 12. The system consists of two spatial elements, frost boil and inter-boil area. Each element consists of three components, the ice lenses, which are responsible for heave, the soils and the biogeochemical cycles within them, and the vegetation. The large bold arrows in Figure 12 indicate interactions between the frost boil and the inter-boil area, namely via gravity (the flow of water and material from the frost boil to the inter-frost boil) and by cryosuction (movement of water from the inter-boil area to the frost boil during winter). Within each element, the thin arrows indicate interactions between the components. The interactions between the soil and the ice lenses are primarily related to the influence of soil texture on ice segregation and the organic soil horizons on the insulation properties of the soil, which reduce heat flux into and out of the soil. Effects of the ice lenses on the soil include changes to soil structure and chemistry, soil aeration, mineralization, and sorting of soil particles. The interactions between the soil and the vegetation include supply of nutrition and water. Vegetation effects on the soil are primarily related to the accumulation of organic material and nutrients. The interaction between the vegetation and the ice lenses is mainly the insulation effects that affect the active-layer thickness and the rate of freezing. Finally, the ice lenses influence the vegetation through frost heave.

The strength of the interactions between components of the system is controlled to large extent by the prevailing climate (Figure 13). In the coldest parts of 


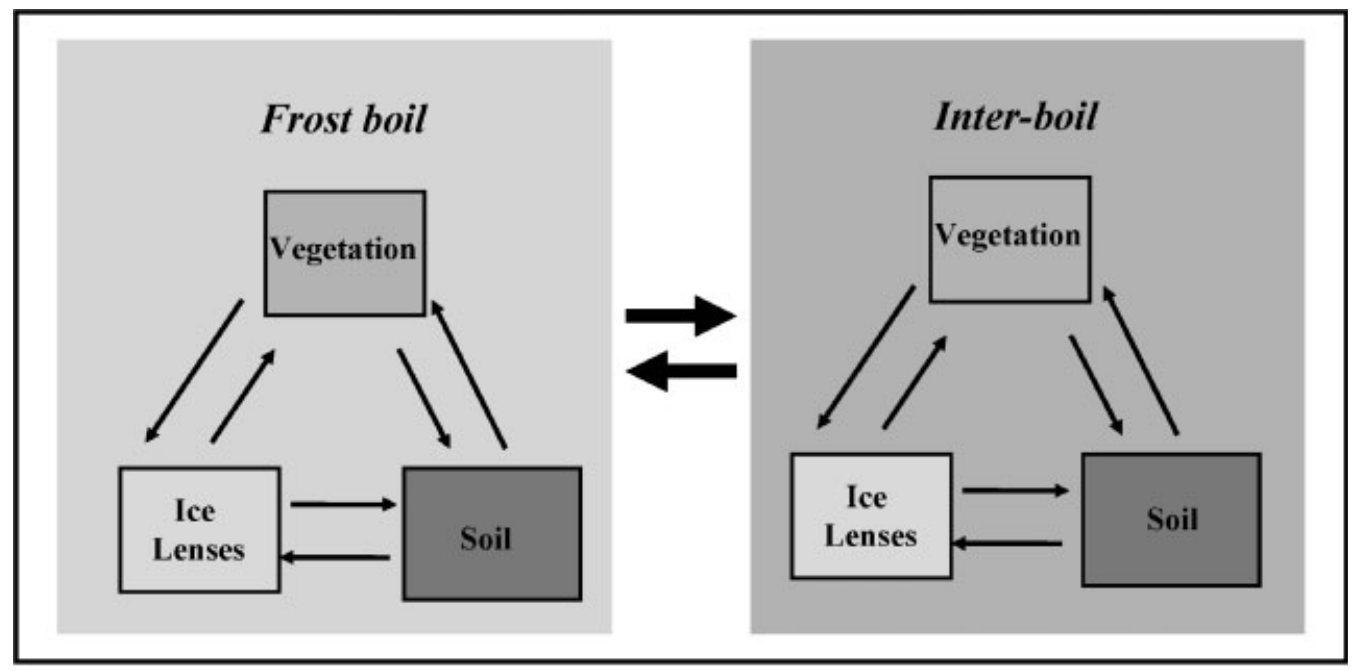

Figure 12 The frost-boil system. The arrows indicate interactions and feedbacks between elements (frost boils and inter-boils), and between components of each element (ice lenses, soils, and vegetation). See text for explanation of the interactions between the elements and components.

the High Arctic (Subzone A), biological processes are weak. The physical processes governing frost heave and soil formation are dominant in both the frost boils and the inter-boil elements. The vegetation component has little effect on the system in either element. There is little differential heave and poor development of frost boils. In Middle-Arctic (Subzone C) climates, the vegetation component is quite active in the interboil element, but conditions similar to those in the High Arctic are maintained on the frost boils. Physical processes dominate on the frost boil element creating barren habitats, but there is a nearly complete cover of plants in the inter-frost-boil areas. The strong contrast between the boils and inter-boils creates conditions for maximum differential heave, and frost boils are well expressed (Figure 1). In the relatively warm southern Low-Arctic climates (Subzone E), biological processes dominate in both elements of the frost-boil system. There is a longer growing season, warmer soils, and a greater diversity of plants, with more above-ground and below-ground biological activity. As a consequence, plants are able to counteract the effects of frost heave and needle-ice formation. There is a nearly-complete cover of plants on both elements (see Figure 9) and there is usually poor surface expression to the frost boils because of thick vegetation mats.

\section{The Role of Frost Boils in Tundra Ecosystem Dynamics}

Recent studies have noted that frost boils are linked to a wide variety of ecosystem properties, including regional patterns of thaw-layer thickness (Nelson et al., 1997), nutrients (Broll et al., 1999; Jonasson and Skold, 1983), carbon sequestration (Bockheim et al., 1998; Ping et al., 1998), fluxes of energy and water (Walker et al., 1998), plant species richness (Gough et al., 2000; Walker et al., 1998), and forage quality for wildlife (Walker et al., 2001) (Figure 14). In the Low Arctic frost boils help to maintain high soil $\mathrm{pH}$. Paleoecological studies of Arctic landscapes recognize the important role of changes in soil $\mathrm{pH}$ that led to the transition from a mineral-rich environment during the Pleistocene to the modern day paludified ecosystems that cover much of northern Alaska (Mann et al., 2002; Oswald et al., 2003; Walker et al., 2001).

Soils in the frost boils have surprisingly large stores of carbon and nutrients frozen in the permafrost. This carbon is of concern in studies of global climate change because it represents a possible source of additional greenhouse gases to the atmosphere (Chapin et al., 1997; Oechel et al., 1997; Rastetter and Shaver, 1992). In addition to being a large store of carbon, tundra soil organic matter contains substantial quantities of nitrogen, which when mineralized to an inorganic form (ammonium or nitrate), or in some cases to amino acids, provides a nutrient source for plants and soil organisms. Because of the generally cold and saturated soils of the tundra, the mineralization process is slow (Giblin et al., 1991), and arctic ecosystems tend to be strongly limited by available nitrogen (Shaver et al., 2001). Differences in the soil environment between frost boils and inter-boil areas, including differences in soil moisture, temperature, 


\section{Frost boils Inter-boils}

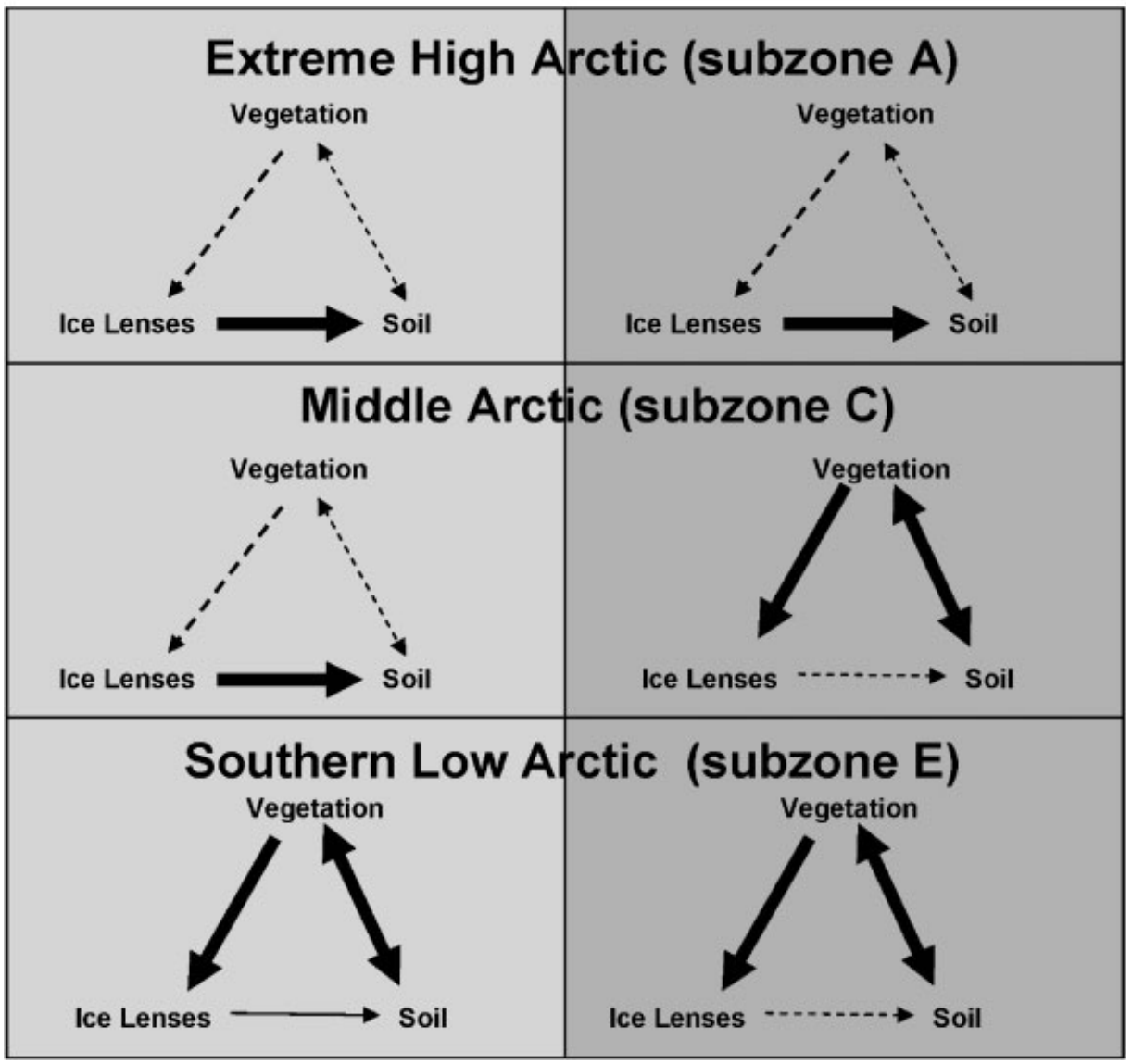

Figure 13 Hypothesized response of the frost-boil system along the Arctic bioclimate gradient. Arrows indicate strength and direction of primary interaction between components of the system. Bold arrows indicate dominant interactions, dashed arrows are weak interactions. See text for details of interactions in the three subzones.

active layer depth, and the quantity and quality of the soil organic matter, are due largely to the presence or absence of vegetation. Nitrogen cycling is likely to be quite different on frost boils compared to inter-boil areas and probably plays an important role in the succession of vegetation on frost boil soils.

Most studies indicate that climate warming will promote thicker active layers, which would mobilize carbon and nitrogen because of increases in heterotrophic respiration (Rastetter et al., 1991). If the availability of nitrogen increases in the soil, particularly in areas with extremely low soil nitrogen, plant growth would be promoted. However, a related study (Walker et al., 2003) indicates that in the zonal areas of Subzone E, air temperature has a diminished influence on soil temperatures and the thickness of the thaw layer because of the confounding influences of the vegetation mat. Warmer temperatures do promote deeper thaw, but they also promote more plant growth, which tends to insulate the soil and prevent deep thaw. Warmer temperatures also reduce the effect of cryoturbation, which stirs the soil carbon to deeper levels in the thaw layer, where it can be incorporated into the permafrost table. These complex interactions between climate, cryoturbation, vegetation, soil carbon, and permafrost make the net effect on carbon and nutrient cycling far from clear.

The response of frost-boil systems to climate change will differ in each subzone. In the High Arctic (subzones A and B), organic-matter accumulation would focus in the inter-boil areas, but probably not on the frost boils. Landscape heterogeneity would, therefore, likely increase in Subzones A and B. In subzones $\mathrm{C}$ and $\mathrm{D}$, a long-term increase of soil organic 


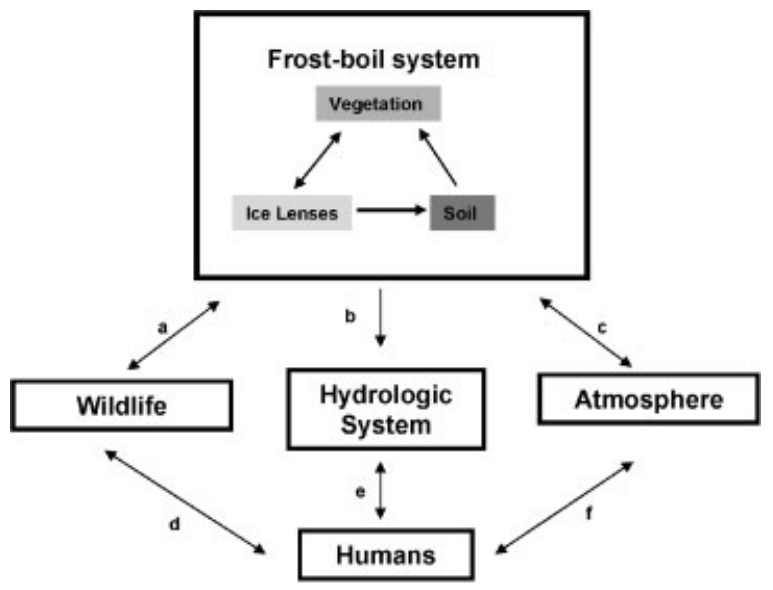

Figure 14 Linkages between the frost-boil system and components of the greater Arctic system and biosphere. Arrows that indicate the linkages between subsystem components within the frost-boil system are shown more explicitly in Figure 12 and described in the text. The linkages to the greater Arctic system are (a) effects on forage quality and wildlife habitat, (b) effects on water flux and water quality, and (c) fluxes and energy ant trace gases to the atmosphere. These components are important to humans because of their effects on (d) availability of game, (e) fish and water resources, and (f) climate change.

matter on zonal sites would likely increase the growth of the plants on the frost boils and the inter-boil areas, and decrease the thickness of the thaw layer.

In Subzone E, warmer temperatures would probably not have immediate effects on the frost-boil patterns because they are already masked by thick vegetation mats. In some parts of Subzone E, shrub growth may convert tussock tundra to shrub tundra (Sturm, 2001; Silapaswan, 2001) where frost boils are usually not abundant. In some areas, permafrost may vanish altogether leaving only relict frost boils.

\section{CONCLUSION}

Frost-boil ecosystems are widespread throughout the Arctic, but little is known about their role in the functioning of the total Arctic system. The frost boils along the climate gradient in Alaska are typical of zonal situations on ice-rich fine-grained soils elsewhere in the Low Arctic. The conceptual model of frost boil ecosystems presented here is a hypothesis of frost-boil morphology-soil-vegetation-heave interactions along a complete climate gradient. Studies of other frost-boil ecosystem components and processes are needed, including but not limited to, (a) energy and trace gas fluxes, (b) water and nutrient flux to streams, (c) effect of cryoturbation on the carbon in the intermediate layer (near-surface), and (d) nutrient cycling, especially in relationship to studies of animal habitat at several scales.

\section{ACKNOWLEDGEMENTS}

Marilyn Walker's contributions to the ideas leading to the conceptual diagrams in Figures 14 and 15 are much appreciated. The Geophysical Institute, the Institute of Arctic Biology, and Veco Polar Resources, Inc. provided considerable cooperative logistic support. Funding was provided by the National Science Foundation grants OPP-0120736 and OPP-9908829 and a grant from the International Arctic Research Center. Additional support was provided by several NSF Research Experience for Undergraduate (REU) supplements. This work would not have been possible without the help of several field assistants and students who participated in the field studies including Lindsey Kiez, David Wirth, Amber Moody, Erica Edwards and Corinne Munger.

\section{REFERENCES}

Alexandrova VD. 1980. The Arctic and Antarctic: Their Division into Geobotanical Areas. Cambridge University Press: Cambridge.

Bockheim JG, Walker DA, Everett LR, Nelson FE, Shiklomanov NI. 1998. Soils and cryoturbation in moist nonacidic and acidic tundra in the Kuparuk river basin, arctic Alaska, U.S.A. Arctic and Alpine Research 30: 166-174.

Broll G, Tarnocai C, Mueller G. 1999. Interactions between vegetation, nutrients and moisture in soils in the Pangnirtung Pass Area, Baffin Island, Canada. Permafrost and Periglacial Processes 10: 265-277.

Brown J, Hinkel KM, Nelson FE. 2000. The circumpolar active layer monitoring (CALM) program: research designs and initial results. Polar Geography 24: 165-258.

CAVM Team. 2003. Circumpolar Arctic Vegetation Map (Scale 1:7500 000). Anchorage, AK: conservation of Arctic Flora and Fauna (CAFF) Map No. 1, U.S. Fish and Wildlife Service.

Chapin FS, III, McFadden JP, Hobbie SE. 1997. The role of arctic vegetation in ecosystem and global processes. In Ecology of Arctic Environments, Woodin SJ, Marquiss M (eds). Blackwell Science: Oxford; 97-112.

Chernov YI, Matveyeva NV. 1997. Arctic ecosystems in Russia. In Polar and Alpine Tundra, Vol. 3, Wielgolaski FE (ed.). Elvesier: Amsterdam; 361-507.

Dyke AS, Zoltai SC. 1980. Radiocarbon-dated mudboils, central Canadian Arctic. Geological Survey of Canada, Current Research, Part B 80: 271-275.

van Everdingen R (ed.). 2002. Multi-Language Glossary of Permafrost and Related Ground-Ice Terms. National 
Snow and Ice Data Center/World Data Center for Glaciology: Boulder, CO.

Fowler AC, Krantz WB. 1994. A generalized secondary frost heave model. SIAM Journal of Applied Mathematics 54: 1650-1675.

Gardner WH. 1986. Water Content. In Methods of Soil Analysis, Part 1: Physical and Mineralogical Methods, Klute A (ed.). American Society of Agronomy and Soil Science Society of America: Madison, WI; 493-495.

Giblin AE, Nadelhoffer KJ, Shaver GR, Laundre JA, McKerrow AJ. 1991. Biogeochemical diversity along a riverside toposequence in arctic Alaska. Ecological Monographs 61: 415-435.

Gilpin RR. 1980. A model for the prediction of ice lensing and frost heave in soils. Water Resources Research 16: 1650-1675.

Gough L, Shaver GR, Carroll J, Royer DL, Laundre JA. 2000. Vascular plant species richness in Alaskan arctic tundra: the importance of soil pH. Journal of Ecology 88: $54-66$.

Gould WA, Walker DA, Biesboer D. 2003. Combining research and education: bioclimate zonation along a Canadian Arctic transect. Arctic 56: 45-54.

Goward SN, Tucker CJ, Dye DC. 1985. North American vegetation patterns observed with the NOAA-7 advanced very high resolution radiometer. Vegetatio 64: 3-14.

Hope AS, Fleming JB, Vourlitis G, Stow DA, Oechel WC, Hack T. 1995. Relating $\mathrm{CO}_{2}$ fluxes to spectral vegetation indices in tundra landscapes: importance of footprint definition. Polar Record 31: 245-250.

Hope AS, Kimball JS, Stow DA. 1993. The relationship between tussock tundra, spectral reflectance properties, and biomass and vegetation composition. International Journal of Remote Sensing 10: 1861-1874.

Jia GJ, Epstein HE, Walker DA. 2002. Spatial characteristics of AVHRR-NDVI along latitudinal transects in northern Alaska. Journal of Vegetation Science 13: 315-326.

Jia GJ, Epstein HE, Walker DA. 2004. Controls over intra-seasonal dynamics of AVHRR NDVI for the Arctic tundra in northern Alaska. Int. J. Remote Sensing: 1-18, preview article.

Jonasson S, Skold SE. 1983. Influences of frost-heaving on vegetation and nutrient regime of polygonpatterned ground. Vegetatio 53: 97-112.

Kessler MA, Murray AB, Werner BT, Hallet B. 2001. A model for sorted circles as self-organized patterns. Journal of Geophysical Research 106: 13287-13306.

Kessler MA, Werner BT. 2003. Self-organization of sorted patterned ground. Science 299: 380-383.

Mann DH, Peteet DM, Reanier RE, Kunz ML. 2002. Responses of an arctic landscape to Late glacial and early Holocene climatic changes: the importance of moisture. Quaternary Science Reviews 21: 997-1021.

Markon CJ. 1999. Characteristics of the Alaskan 1-km Advanced Very High Resolution Radiometer data sets used for analysis of vegetation biophysical properties: US Geological Survey, Open File Report 99-088.
Matveyeva NV. 1998. Zonation in Plant Cover of the Arctic. Russian Academy of Sciences, Proceedings of the Komarov Botanical Institute, No. 21 (in Russian).

Nelson FE, Shiklomanov NI, Mueller GR, Hinkel KM, Walker DA, Bockheim JG. 1997. Estimating activelayer thickness over a large region: Kuparuk River Basin, Alaska. Arctic and Alpine Research 29: 367-378.

Oechel WC, Cook AC, Hastings SJ, Vourlitis GL. 1997. Effects of $\mathrm{CO}_{2}$ and climate change in arctic ecosystems. In Ecology of Arctic Environments, Woodin SJ, Marquiss M (eds). Blackwell Science: Oxford; 255-273.

Oswald WW, Brubaker L, Hu FS, Kling GW. 2003. Holocene pollen records from the central Arctic Foothills, northern Alaska: testing the role of substrate in the response of tundra to climate change. Journal of Ecology 91: 1034-1048.

Peterson RA, Krantz WB. 2003. A mechanism for differential frost heave and its implications for patterned ground formation. Journal of Geology 49: 69-80.

Peterson RA, Walker DA, Romanovsky VE, Knudson JA, Raynolds MK, Krantz WB. 2003. A differential frost heave model: cryoturbation-vegetation interactions. In Permafrost: Proceedings of the Eighth International Conference on Permafrost, Vol. 2, Phillips M, Springman SM, Arenson LU (eds). A. A. Balkema Publishers: Zurich, Switzerland, Lisse; 885-890.

Ping CL, Bockheim JG, Kimble JM, Michaelson GJ, Walker DA. 1998. Characteristics of cryogenic soils along a latitudinal transect in Arctic Alaska. Journal of Geophysical Research 103: 28917-28928.

Ping CL, Michaelson GJ, Kimble J, Shur YL, Walker DA. 2002. Morphogenesis of soils associated with frost boils. Eos, Transactions, American Geophysical Union 83: F259.

Polunin N. 1951. The real Arctic: suggestions for its delimitation, subdivision and characterization. Journal of Ecology 39: 308-315.

Rastetter EB, Ryan MG, Shaver GR, Melillo JM, Nadelhoffer KJ, Hobbie JE, et al. 1991. A general biogeochemical model describing the responses of the $\mathrm{C}$ and $\mathrm{N}$ cycles in terrestrial ecosystems to changes in $\mathrm{CO}_{2}$, climate, and $\mathrm{N}$ deposition. Tree Physiology 9: 101-126.

Rastetter EB, Shaver GR. 1992. A model of multipleelement limitation for acclimating vegetation. Ecology 73: 1157-1174.

Romanovsky VE, Osterkamp TE. 1995. Interannual variations of the thermal regime of the active layer and near-surface permafrost in Northern Alaska. Permafrost and Periglacial Processes 6: 313-335.

Romanovsky VE, Osterkamp TE. 1997. Thawing of the active layer on the coastal plain of the Alaskan Arctic. Permafrost and Periglacial Processes 8: 23-44.

Rouse JW, Hass RH, Schell JA, Deering DW. Monitoring vegetation systems in the great plains with ERTS. Third ERTS Symposium, Vol. 1. NASA (SP-351): Greenbelt, MD, 1973: 309-317. 
Shaver GR, Bret-Harte MS, Jones MH, Johnstone J, Gough L, Laundre J, et al. 2001. Species composition interacts with fertilizer to control long-term change in tundra productivity. Ecology 82: 3163-3181.

Shippert MM, Walker DA, Auerbach NA, Lewis BE. 1995. Biomass and leaf-area index maps derived from SPOT images for Toolik Lake and Imnavait Creek areas, Alaska. Polar Record 31: 147-154.

Shur Y. 1988. The upper horizon of permafrost soils. Proceedings of the 5th International Permafrost Conference, Vol. 1. Tapir Publishers: Trondheim, Norway; 867-871.

Silapaswan CS, Verbyla D, McGuire AD. 2001. Land cover change on the Seward Peninsula: the use of remote sensing to evaluate potential influences of climate change on historical vegetation dynamics. Journal of Remote Sensing 5: 542-554.

Simmons CL, Walker DA, Webber PJ, Everett KR. 1981. Sea-water sensitivities of selected plant communities of Prudhoe Bay, Alaska. U.S. Army Cold Regions Research and Engineering Laboratory: Hanover, NH; 41.

Soil Survey Staff. 1993. Soil Survey Manual, USDA Handbook No. 18. US Government Printing Office: Washington, DC.

Sturm M, McFadden JP, Liston GE, Chapin FS, III, Racine CH, Holmgren J. 2001. Snow-shrub interac- tions in arctic tundra: a hypothesis with climatic implications. Journal of Climate 14: 336-344.

Walker DA, Auerbach NA, Bockheim JG, Chapin FSI, Eugster W, King JY, et al. 1998. Energy and trace-gas fluxes across a soil $\mathrm{pH}$ boundary in the Arctic. Nature 394: 469-472.

Walker DA, Bockheim JG, Chapin FSI, Eugster W, Nelson FE, Ping CL. 2001. Calcium-rich tundra, wildlife, and the 'Mammoth Steppe'. Quaternary Science Reviews 20: 149-163.

Walker DA, Jia GJ, Epstein HE, Raynolds MK, Chapin FS, III, Copass CD, et al. 2003. Vegetation-soilthaw-depth relationships along a low-arctic bioclimate gradient, Alaska: synthesis of Information from the ATLAS Studies. Permafrost and Periglacial Processes 14: $103-123$.

Walker MD, Walker DA, Auerbach NA. 1994. Plant communities of a tussock tundra landscape in the Brooks Range Foothills, Alaska. Journal of Vegetation Science 5: 843-866.

Westhoff V, van der Maarel E. 1978. The Braun-Blanquet approach. In Classification of Plant Communities, Whittaker RH (ed.). Dr. W. Junk: Den Haag; 287-399.

Young SB. 1971. The vascular flora of St. Lawrence Island with special reference to floristic zonation in the arctic regions. Contributions from the Gray Herbarium 201: 11-115. 